\title{
From the Perspective of Structuralism, the Dilemma and Path Selection of Colleges and Universities to Practice Socialist Core Values
}

\author{
Dong Wang \\ School of public administration, nanjing normal university, China \\ 1244607450@qq.com
}

\begin{abstract}
Practice the socialist core values of colleges and universities is facing the information age to enhance ideological and political education work effectiveness of one of the important methods in the process of practice in colleges and universities neglect the whole systemic, on time field education main body education platform there are structural difficulty, need to be researched, the theme, respect the main body function, perfect the education platform, clarify the logical relationship, to construct the complete function of perfect structure of socialist core values education guide mechanism, promote the new development of ideological and political work in colleges and universities, for the socialist modernization construction create a good cultural environment.
\end{abstract}

KEYWORDS: Socialist core values, Structural dilemmas, way

\section{Introduction}

Structuralism, "which is not a philosophy but a methodology, plays an important role in modern western social sciences”. [1] Is tool rational guidance for social science research in the study of complex phenomena, the need to take the research object is divided into several parts, then reassembled and establish new contacts, to cause the change of the integrity of structuralism is referred to the deep structure of the development of things, that the "decided to social and cultural history, the basic rules for specific events and behavior as a whole”. [2] Education in France sociologist Pierre bourdieu Swiss psychologist piaget and the American education historian bruner and others, with the help of structuralism in the field of education research has achieved fruitful research results, deeply affects the overall development of pedagogy structuralism of pedagogy research, is actually to decode the activities of education and cultural symbol, and the school is really a good place for study of symbol and symbolic system. [3] School education is the main position, 
are important platform of socialization For education in colleges and universities, is itself a system structure of related integration education resources and the construction of education main body, is part of the construction of the society as a whole, is also the basic requirement of self function The socialist core values is the new development of marxism in the field of social values, as we must adhere to the value orientation of, is fundamental to the all-round development of individuals and countries.

\section{The structural dilemma of practicing socialist core values in colleges and universities}

According to the 39th statistical report on the development of China's Internet network released by China Internet network center (CNNCI), the number of Chinese netizens reached 731 million as of December 2016, and a total of 43.99 million new netizens were added in the year, with a growth rate of 6.2 percent. 695 million mobile Internet users, the growth rate of more than $10 \%$ for three consecutive years, the college students' Internet users and the growth rate is significantly increased, the network has become an important part of college students' daily life in university is faced with the transformation of school education transformation, mainly to enhance the effectiveness of socialist core values, avoid fissionability fragmentation of the embarrassing situation.

Teachers and students is the main part of the practice of socialist core values of colleges and universities, colleges and universities to unified whole teaching platform for the structured, the professional quality of teachers and students' learning enthusiasm for the firm as well as the influence of the propaganda of socialist core values is put forward in the style orientation of teachers become the realization of the ideological and political theory course teaching transformation of two key links," namely to realize teaching material system into the teaching system of teaching system into a student's knowledge and belief system”. [4] In the actual teaching process, the teacher is the whole participant of the teaching effect of teaching tasks and teaching objectives.

Students is the direct object of teaching, also is the fundamental aim at for the work of ideological and political education, students attention degree is not high, a test of the phenomenon is very outstanding, among different departments professional are common there For socialist core values, many students just simple understanding stage, there is not even understand the basic content of college education propaganda effect is very limited In the architecture of teacher student interaction and initiative of students has not been fully respect, no real sense of engagement and build.

Campus culture of the traditional classroom teaching and new media, is the practice of socialist core values of the basic platform, is an integration with The Times change constantly restructuring sort of embedded structure, three common role in college education, in turn, because of the change of actual college education demand, the amount of weight change this combination has a propensity to 
education platform, including the contact relation of weight and are hard to straighten out and defined, the confusion of the concept of neglect makes it hard for the resultant force and operational highlights, optimization combination is still in exploring, and it is a complex dynamic process.

Campus culture is the practice of socialist core values of the basic platform, is to plan as a whole group culture needs the teachers and students The main carrier of school culture construction of facilities At present, the construction of school culture is the phenomenon of heavy technology, light humanities, the discipline development, for the publicity and education of ideological and political work into formal superficial, cultural norms and the ideological education in the relatively weak position; There exists the phenomenon of valuing hardware over software, regarding the construction of cultural infrastructure as an important link of cultural environment, unilaterally pursuing visual engineering and neglecting the construction of student-oriented cultural soft power.

New media, is the practice of socialist core values of the network platform, is to respect students' individual demand of information age important medium of the moment the emergence of new media, more spontaneous state, namely the individual students get a lot of information in the new media, and the information is not filtered, a serious flood of information and information pollution and corrosion on college students' ideological and easily.

\section{The path of education and the guiding mechanism of the socialist core values in colleges and universities}

Practice the socialist core values of college and university is active occupy new ground for the spread of socialist ideology, to carry forward the era theme Comply with the network development trend, comprehensively strengthen the university cultural construction, starting from the relevant part of the structured internal, constantly broaden the channels of the practice of socialist core values The new space, realize the depth of the college students education and guidance.

Grasp the era theme, based on social development, to achieve social transformation in the field to promote the practice of the firmness of socialist core values The first thing to face cultural diversity of social transformation, with an open mind in the face of foreign culture, seeking common ground while putting aside differences, seek common development In cultural exchanges, understanding personality, respect for differences in the selective absorption of the development of the localization of foreign culture of socialist core values as a mainstream culture, must strengthen in the comparison with foreign culture fusion itself, especially for the college students Secondly, in the trend of the Internet age, we should reform the guiding mechanism of colleges and universities to practice socialist core values, change the single mode of indoctrination education in the traditional mode, and improve the system and mechanism of practicing socialist core values in the increasingly diverse network demands of students. 
Respect the main body status, main functions and build a new two-dimensional relationship between teachers and students first, fully respect the teachers teaching in the practical teaching supervisors the role of the executor, reshape the leading role of teachers in teaching activities, actively guide college students to carry on the rational judgment and rational choice, with the socialist core values its students political ideal value must sum of moral quality, achieve teaching basic goal to build the corresponding incentive mechanism, support to guarantee teachers into tangible rewards, inspire the enthusiasm of working enthusiasm and promote socialist core values Secondly, we should return to the student-oriented education concept, fully consider the differences between students and carry out targeted education of socialist core values.

Attaches great importance to the platform construction, and promote the coconstruction and communion between platform, platform play the biggest force in the first place, the campus culture to fully meet the need of construction of socialist core values the omnidirectional and multi-level, from two aspects of hardware software culture atmosphere to speed up the optimization and development of the cultural environment, change the phenomenon of heavy light humanities and light practice, cultivating public participation in the balanced development of university culture and, second, the urgent task of classroom teaching platform lies in the efforts to adapt to the trend of network development, change the traditional teaching mode, increase the attractive school way, so as to enhance students autonomy in the teaching goal On the teaching form and content of organic unity and the strategy and the force, especially the main teaching of the socialist core values of ideological and political theory course, collective lesson preparation prepared with scientific planning, detailed interpretation of the theory knowledge, comprehensive on classroom teaching and to strengthen the supervision and examination of student, ensure teaching caught out.

\section{Conclusion}

Practice the socialist core values of colleges and universities is facing many problems, in the new era under the new historical conditions at the same time also ushered in the new development opportunity, how to grasp the new era, the good opportunity of development, promote the widespread dissemination of socialist core values, is one of the important problems in colleges and universities must solve From the perspective of structuralism, the analysis of relevant problems, and put forward appropriate on the basis of the feasible way to solve, many aspects to promote the spread and development of the socialist core values.

\section{References}

[1] Philosophy translation editorial board, Materials from major western philosophical schools in modern times, The Commercial Press, 1981, p203.

[2] You-zheng Li, The study of interdisciplinary epistemology in the humanities, China Social Sciences Press, 1996, p150. 
[3] Gibson, Structuralism versus education, Wunan book publishing company, 1995, p32.

[4] Wanggang, Wangyue, The network teaching platform is used to promote the ideological and political theory course in colleges and universities to realize two transformations, Ideology Education, Vol.22 (2015) No.3, p.65-68. 